Images in...

\title{
Non-syndromic supernumerary premolars
}

\author{
Amitabh Kallury, ${ }^{1}$ Upendra Jain, ${ }^{2}$ Suma Shekhar, ${ }^{1}$ Gagan Thakur ${ }^{3}$ \\ 1Department of Orthodontia, People's Dental Academy, Bhopal, Madhyapradesh, India; \\ 2Department of Orthodontia, People's College of Dental Sciences \& Research Centre, Bhopal, Madhyapradesh, India; \\ ${ }^{3}$ Department of Oral and Maxillofacial Surgery, People's College of Dental Sciences and Research Centre, Bhopal, Madhyapradesh, India
}

Correspondence toDr Gagan Thakur, drgagan05@yahoo.com

\section{DESCRIPTION}

A 22-year-old male reported with the chief complaint of spacing between front teeth and unpleasant smile. Medical and dental history was non-contributory. Intra oral examination revealed Angle's class I molar relationship with midline diastema. Bilateral supplementary mandibular premolars were noted in linguoversion (figure 1). Radiographic examination revealed an impacted supernumerary maxillary premolar between right first and second premolars (figure 2). Supernumeraries can appear in both deciduous $(0.3 \%-0.6 \%)$ and permanent dentitions $(1 \%-3.5 \%) .{ }^{1}$ The male to female ratio is $2: 1$. The most common supernumerary tooth is mesiodens, followed by maxillary lateral incisor, maxillary fourth molar and mandibular third premolar supernumeraries. Supernumerary premolars constitute approximately $10 \%$ of the total supernumerary cases, and almost $75 \%$ of those are in the mandible. ${ }^{2}$ Mandibular supernumerary premolars usually resemble the permanent premolars in both size and shape. Although this problem seems to be caused by genetic or environmental factors, the aetiology is unknown. Supernumerary teeth cause certain clinical problems such as failure to erupt, displacement of a permanent tooth, crowding, or dentigerous cyst formation. Treatment is aimed at extraction of supernumeraries before problems arise, or at minimising the effect if other teeth have already been displaced. ${ }^{3}$

Competing interests None.

Patient consent Obtained.

\section{REFERENCES}

1. Esenlik E, Sayin MO, Atilla AO, et al. Supernumerary teeth in a Turkish population. Am J Orthod Dentofacial Orthop 2009;136:848-52.

2. Hyun HK, Lee SJ, Ahn BD, et al. Nonsyndromic multiple mandibular supernumerary premolars. J Oral Maxillofac Surg 2008;66:1366-9.
3. Proffit WR, Flields HW, Sarver DM. Treatment of nonskeletal problems in preadolescent children. In: Contemporary Orthodontics. Fourth Edition. St Louis: Mosbey 2007:449.

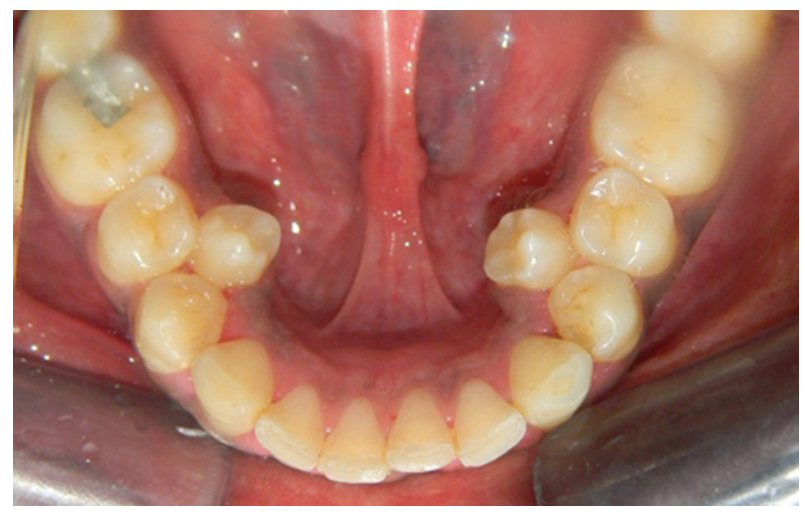

Figure 1 Intra oral view.

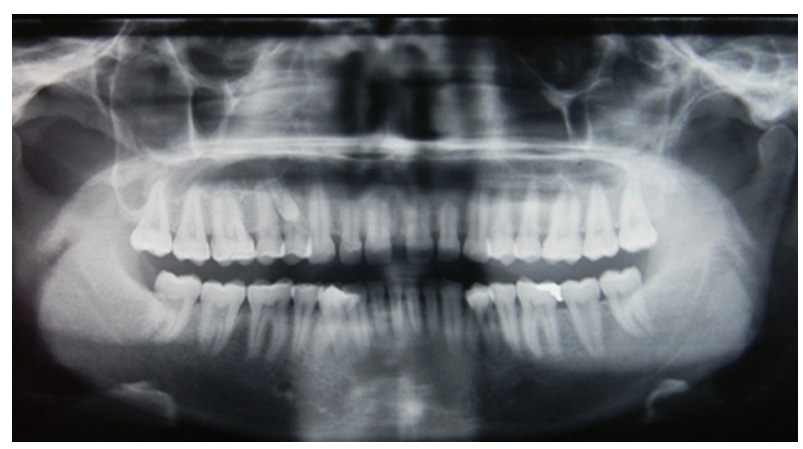

Figure 2 Orthopantomograph. 


\section{BMJ Case Reports}

This pdf has been created automatically from the final edited text and images.

Copyright 2011 BMJ Publishing Group. All rights reserved. For permission to reuse any of this content visit http://group.bmj.com/group/rights-licensing/permissions.

BMJ Case Report Fellows may re-use this article for personal use and teaching without any further permission.

Please cite this article as follows (you will need to access the article online to obtain the date of publication).

Kallury A, Jain U, Shekhar S, Thakur G. Non-syndromic supernumerary premolars. BMJ Case Reports 2011;10.1136/bcr.08.2011.4680, date of publication

Become a Fellow of BMJ Case Reports today and you can:

- Submit as many cases as you like

- Enjoy fast sympathetic peer review and rapid publication of accepted articles

- Access all the published articles

- Re-use any of the published material for personal use and teaching without further permission

For information on Institutional Fellowships contact consortiasales@bmjgroup.com

Visit casereports.bmj.com for more articles like this and to become a Fellow 